\title{
Correction to: Joint power optimization and scaled beamforming approach in B5G network based massive MIMO enabled HetNet with full-duplex small cells
}

\author{
Malini Balachandran $^{1}$ - Noor Mohammed Vali Mohamad ${ }^{1}$ \\ Published online: 24 November 2020 \\ (C) Springer Science+Business Media, LLC, part of Springer Nature 2020
}

Correction to: Peer-to-Peer Netw. Appl.

https://doi.org/10.1007/s12083-020-00998-Z

Corrections are needed to the original article due a mismatch between equation citations and equation labels.

The original article has been corrected.

Publisher's note Springer Nature remains neutral with regard to jurisdictional claims in published maps and institutional affiliations.

The online version of the original article can be found at https://oi.org/ 10.1007/s12083-020-00998-Z

Noor Mohammed Vali Mohamad

noorb4u@gmail.com

1 School of Electronics Engineering, Vellore Institute of Technology, Vellore, India 